\title{
ADDITIVE FABRICATION OF BIOCERAMIC/BIOPOLYMER BONE IMPLANTS: A CASE STUdY
}

\author{
CRUZ, F. \& COOLE, T.
}

Abstract: This chapter presents an overview of the research work carried out in the last few years for the rapid manufacture of hydroxyapatite (HA) based components by means of the SLS (Selective Laser Sintering) technology, to be used for bone tissue implantation, aiming to replace and/or repair bone defects due to traumatized, damaged or lost bone. SLS is an Additive Manufacturing Technology (AMT) that selectively sinters powders of engineering materials by means of a $\mathrm{CO}_{2}$ laser. $\mathrm{HA}$ is a bioceramic used since several years for medical applications although being mainly processed by conventional methods (cast, machined, or manually produced). For that purpose CAD/CAM software, Rapid Manufacturing Technologies (RMT) and Medical Imaging Techniques (MRI) were integrated, and this enabled the customized production of anatomical models. This approach provides a direct method of producing HA based prostheses.

Key words: Additive Fabrication, Rapid Manufacturing, Direct Bone Implants, BioComposites, Selective Laser Sintering
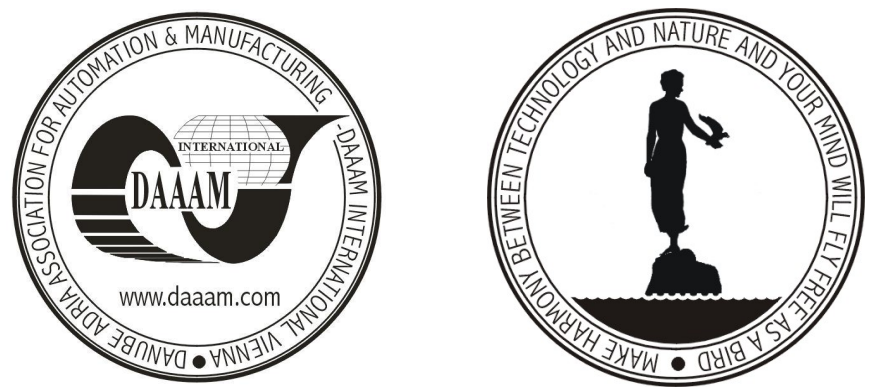

Authors' data: MSc. PhD. Cruz, F[ernando]*; PhD. Coole, T[im]**, * Mechanical Engineering Department / School of Technology of Setubal / Polytechnic Institute of Setubal / Portugal, Campus do IPS, Estefanilha, 2910-761 Setubal, Portugal, ** Faculty of Technology/Buckinghamshire Chilterns University College, Queen Alexandra Road, High Wycombe, HP 11 2JZ, Bucks, UK, fcruz@est.ips.pt, t.coole@bcuc.ac.uk

This Publication has to be referred as: Cruz, F. \& Coole, T. (2007). Additive Fabrication of Bioceramic/Biopolymer Bone Implants: A Case Study, Chapter 29 in DAAAM International Scientific Book 2007, B. Katalinic (Ed.), Published by DAAAM International, ISBN 3-901509-60-7, ISSN 1726-9687, Vienna, Austria DOI: $10.2507 /$ daaam.scibook.2007.29 